\title{
Sportske ozljede i oštećenja ručnog zgloba i šake
}

\section{Wrist and hand sports injuries and lesions}

\author{
Dina Hrabar ${ }^{1}$, Zdravko Jotanović ${ }^{2 *}$
}

${ }^{1}$ Opća bolnica Šibensko-kninske županije, Šibenik

${ }^{2}$ Klinika za ortopediju i traumatologiju Lovran, Katedra za ortopediju i fizikalnu medicinu, Lovran

\author{
*Dopisni autor: \\ Doc. dr. sc. Zdravko Jotanović, dr. med., \\ spec. ortopedije \\ Klinika za ortopediju i traumatologiju \\ Lovran, Katedra za ortopediju i fizikalnu \\ medicinu, Referentni centar za bolesti i \\ ozljede koljenog zgloba MZSS RH, \\ Šetalište Maršala Tita 1, 51415 Lovran \\ E-mail: zjotanov@gmail.com
}

Sažetak. Cilj: Prikazati iskustva u operacijskom liječenju sportskih ozljeda i oštećenja ručnog zgloba i šake u posljednjih 10 godina. Ispitanici i metode: $U$ ovo istraživanje uključeno je 70 pacijenata kod kojih je učinjeno 70 operacija zbog sportske ozljede ili oštećenja ručnog zgloba i šake u periodu od 1. 3. 2010. do 31. 3. 2020. u Klinici za ortopediju i traumatologiju Lovran. Rezultati: Od 70 pacijenata uključenih u ovo istraživanje, njih 14 (20\%) je ženskog spola, a 56 (80 \%) muškog spola. Raspon dobi pacijenata je od 10 do 50 godina. Prosječna dob pacijenata iznosi $23,7 \pm 8,5$ godina. Kod 35 (50\%) pacijenata bila je zahvaćena lijeva strana, a kod preostalih 35 (50\%) pacijenata desna strana. Kod 34 (49\%) pacijenata sportskom ozljedom ili oštećenjem bila je zahvaćena šaka, dok je kod 36 (51\%) pacijenata sportskom ozljedom ili oštećenjem bio zahvaćen ručni zglob. Od operacijski liječenih sportskih ozljeda u području šake (28) najzastupljeniji su operacijski zahvati osteosinteze prijeloma metakarpalnih kostiju (20) i falangi prstiju (8). Za razliku od operacijski liječenih sportskih ozljeda u području šake, učestalije je operacijsko liječenje sportskih oštećenja negoli ozljeda u području ručnog zgloba $(P<0,001)$. Zaključci: Ovo je prvo istraživanje u našoj populaciji kojim su dobiveni podaci o vrstama sportskih ozljeda i oštećenja ručnog zgloba i šake liječenih operacijski u posljednjih 10 godina. Gotovo $10 \%$ operacija u području ručnog zgloba i šake su operacije sportskih ozljeda i oštećenja. lako su prijelomi najčešći uzrok operacijskog liječenja sportskih ozljeda ručnog zgloba i šake, ozljede i oštećenja mekih tkiva ručnog zgloba i šake također su učestali uzrok operacijskog liječenja.

Ključne riječi: ručni zglob; sportske ozljede, šaka

Abstract. Aim: To present experience in the surgical treatment of wrist and hand sports injuries in the last 10 years. Patients and Methods: The study included 70 patients in which, due to hand and wrist sports injuries and lesions, 70 surgeries were performed in the period from March $1^{\text {st }} 2010$ to March $31^{\text {st }} 2020$ at University Hospital for Orthopedics and Traumatology Lovran. Results: Of the 70 patients included in this study, 14 (20\%) were women and $56(80 \%)$ were men. The age range of the patients was from $10-50$ years, and the average age was $23,7 \pm 8,5$ years. The left side was affected in $35(50 \%)$ patients, and the right side in $35(50 \%)$ patients. The hand was affected in $34(49 \%)$ patients with sports injury. The wrist was affected in $36(51 \%)$ patients with sports injury. Of the surgically treated hand sports injuries (28), the most frequent surgical procedures were treatment of metacarpal (20) and phalangeal (8) fractures. Unlike surgically treated hand sports injuries, surgical treatment of wrist sports lesions is frequently than treatment of wrist sports injuries $(P<0,001)$. Conclusions: This is the first study in our population which collected data about surgically treated wrist and hand sports injuries and lesions in the last 10 years. Nearly $10 \%$ of all wrist and hand surgeries are surgeries of sports injuries and lesions. Although fractures are the most common cause of surgical treatment for sports wrist and hand injuries, wrist and hand soft tissue injuries and lesions are also a common cause of surgery.

Key words: athletic injuries; hand; wrist 


\section{UVOD}

Sportske ozljede predstavljaju globalni zdravstveni problem koji zahtijeva javnozdravstveni pristup kako bi se umanjio njihov utjecaj na zdravlje ${ }^{1}$. Njihovo liječenje predstavlja i financijski problem. Tako je zabilježeno da liječenje sportskih ozljeda kod 5,2 milijuna Australaca stoji australski zdravstveni sustav 2 milijarde australskih dolara (oko 1,2 milijarde eura) $)^{2}$. U Europskoj uniji $20 \%$ svih nefatalnih ozljeda čine sportske ozljede i na njihovo liječenje se izdvaja oko 2,4 milijarde eura ${ }^{3}$. Više od 1,58 milijardi američkih dolara potrošeno je na sportske ozljede u Sjedinjenim Američkim Državama ${ }^{4}$. Učestalost sportskih ozljeda, ali i njima pripadajućih troškova dijagnosticiranja i njihova liječenja, u porastu je ${ }^{5}$. Ono što zabrinjava iz globalne perspektive jest da se podaci o učestalosti sportskih ozljeda u pojedinim populacijama dobivaju izvještajima iz razvijenih zemalja, dok su malo poznati podaci o sportskim ozljedama u nerazvijenim zemljama ${ }^{4}$.

Sljedeći problem koji otežava prikupljanje podataka o učestalosti sportskih ozljeda u pojedinim populacijama, izvještavanje o njima i usporedba $s$ drugim studijama jest činjenica da ne postoji univerzalna definicija sportske ozljede. $U$ većini studija u kojima su se istraživale, sportske ozljede definiraju se kao „poremećaj ili gubitak strukture ili funkcije nastao tijekom sportske aktivnosti koja mijenja sportska postignuća sportaša i dovodi do privremenog ili trajnog prekida bavljenja sportskom aktivnošću" ${ }^{6-7}$. Timpka i sur. definirali su sportske ozljede kao „ozljede tjelesne strukture nastale kao posljedica izloženosti fizičkoj energiji tijekom sportske aktivnosti koje dijagnosticira službeni medicinski djelatnik, a iste mogu dovesti do privremene ili trajne nemogućnosti bavljenja rekreativnim ili profesionalnim sportskim aktivnostima"s.

Sportske ozljede najčešće zahvaćaju sustav za pokretanje (čak do $80 \%$ svih sportskih ozljeda). Svojom učestalošću ističu se, među ostalima, i sportske ozljede ručnog zgloba i šake. Njihova zastupljenost u odnosu na ostale sportske ozljede prema podacima iz literature varira od $3-9 \%$, pa čak do $25 \%^{10-12}$.

S obzirom na činjenicu da nedostaju podaci o liječenju sportskih ozljeda i oštećenja ručnog zgloba i šake u našoj populaciji, cilj ovog istraživanja je prikazati iskustva u operacijskom liječenju sportskih ozljeda i oštećenja ručnog zgloba i šake u posljednjih 10 godina.

\section{ISPITANICI I METODE}

\section{Ispitanici}

U ovom povijesnom kohortnom istraživanju jednog centra uključili smo sve pacijente operirane $u$ Klinici za ortopediju i traumatologiju Lovran u periodu od 1. 3. 2010. do 31. 3. 2020.

Gotovo $10 \%$ operacija u području ručnog zgloba i šake su operacije sportskih ozljeda i oštećenja.

\section{Metode}

Kako bismo dobili točan broj pacijenata operiranih u navedenom razdoblju, koristili smo se računalnim programom Kliničko-bolnički informacijski sustav (u daljnjem tekstu KIBIS). Pretraživanjem KIBIS-a ručno smo izbrojili 37.586 operacija učinjenih u periodu od 1. 3. 2010. do 31. 3. 2020. u Klinici za ortopediju i traumatologiju Lovran (slika 1). Potom smo ručnim pretraživanjem svaku od operacija pretražili pod ključnim riječima (operacije šake i podlaktice, operacije djece, novotvorine, artroskopija ručnog zgloba, alenteze, škljocavi prst, De Quervain, higrom, karpalni kanal) i tako izdvojili operacije u području šake i ručnog zgloba koje su učinjene u navedenom periodu. Daljnjim ručnim pretraživanjem u području šake i ručnog zgloba izdvojili smo operacije koja su učinjene zbog bilo koje ozljede ili oštećenja u području šake i ručnog zgloba. Završnim ručnim pretraživanjem, od operacija šake i ručnog zgloba zbog bilo koje ozljede ili oštećenja, izdvojili smo operacija kod 70 pacijenata učinjenih zbog sportske ozljede ili oštećenja šake i ručnog zgloba u periodu od 1 . 3. 2010. do 31. 3. 2020. u Klinici za ortopediju i traumatologiju Lovran.

Potom smo, pretraživanjem cjelokupne medicinske dokumentacije u KIBIS-u i arhivi Klinike svakog od ispitanika uključenog u ovo istraživanje analizirali sljedeće: spol ispitanika (ženski ili muški), dob ispitanika, koja je strana zahvaćena sportskom ozljedom ili oštećenjem u području šake i ručnog 
zgloba (lijeva ili desna), koje je područje zahvaćeno (šaka ili ručni zglob), vrstu sportske ozljede ili oštećenja u području šake i ručnog zgloba, vrstu operacijskog zahvata koji je učinjen zbog sportske ozljede ili oštećenja u području šake i ručnog zgloba, razdoblje od trenutka nastale ozljede do operacije (oštećenja su kronična i anamnestički se ne mogu dokazati), vrsta sportske aktivnosti koja je dovela do ozljede ili oštećenja u području šake i ručnog zgloba, je li došlo do povratka sportskim aktivnostima nakon operacijskog liječenja sport-

Operacijsko liječenje sportskih ozljeda šake češće je od operacijskog liječenja sportskih oštećenja. Najčešći uzrok operacijskog liječenja sportskih ozljeda šake su prijelomi. Operacijsko liječenje sportskih oštećenja ručnog zgloba češće je od operacijskog liječenja sportskih ozljeda. Najčešći uzrok operacijskog liječenja sportskih oštećenja ručnog zgloba su ozljede mekih tkiva.

skih ozljede ili oštećenja u području šake i ručnog zgloba (ako jest i kada), jesu li se pacijenti nakon operacijskog liječenja sportskih ozljede ili oštećenja u području šake i ručnog zgloba vratili na istu razinu sportskih aktivnosti te jesu li se ispitanici bavili sportskom aktivnošću koja je dovela do ozljede ili oštećenja u području šake i ručnog zgloba rekreativno ili profesionalno.

Kako bismo lakše klasificirali ozljede ili oštećenja u području ručnog zgloba i šake, za potrebe ovog istraživanja u ručni zglob, koji se sastoji od distalnog dijela palčane kosti te skafoida, lunatuma i trikvetruma, uključili smo i distalni dio ulne te distalni radio-ulnarni zglob. Sve ozljede u navedenom anatomskom području klasificirali smo kao ozljede ili oštećenja ručnog zgloba. Ozljede preostalih anatomskih struktura distalno od ručnog zgloba (palac s trapezio-metakarpalnim zglobom, distalni red karpalnih kostiju, metakarpalne kosti, falange prstiju i sve pripadajuće mekotkivne strukture) klasificirali smo kao ozljede ili oštećenja šake.

Istraživanje je odobrilo Etičko povjerenstvo Klinike za ortopediju i traumatologiju Lovran.

\section{Statistika}

Kategorijski podaci prikazani su frekvencijom i relativnom frekvencijom. Razlike u kategorijskim podacima izračunate su $\mathrm{Hi}$ kvadrat testom, a za tablice $2 \times 2$ gdje su $n<5$ upotrijebljen je Fisherov egzaktni test.

Kvantitativni podaci prikazani su odgovarajućim mjerama raspršenja (aritmetičkom sredinom i standardnom devijacijom ili medijanom i kvartilnim rasponom) s obzirom na raspodjelu podataka. Raspodjela kvantitativne varijable dob ispitana je Kolmogorov-Smirnovljevim testom. Razlike u dobi s obzirom na spol izračunate su neparametrijskim Mann-Whitneyjevim testom.

Statistički značajnim smatrani su svi zaključci uz $P$ $<0,05$.

Za statističku obradu podataka korišten je program Medcalc 16.1.0.0. (Mariakerke, Belgija).

\section{REZULTATI}

Ručnim pretraživanjem svake od 37.586 operacija pod ključnim riječima (operacije šake i podlaktice, operacije djece, novotvorine, artroskopija ručnog zgloba, alenteze, škljocavi prst, De Quervain, higrom, karpalni kanal) izdvojili smo 1484 $(3,9 \%)$ operacija u području šake i ručnog zgloba koje su učinjene u navedenom periodu (slika 1). Daljnjim ručnim pretraživanjem od 1484 operacije u području šake i ručnog zgloba izdvojili smo 741 (2\%) operaciju koja je učinjena zbog bilo koje ozljede ili oštećenja u području šake i ručnog zgloba (slika 1). Završnim ručnim pretraživanjem, od 741 operacije šake i ručnog zgloba zbog bilo koje ozljede ili oštećenja izdvojili smo 70 (0,2 \%) operacija kod 70 pacijenata učinjenih zbog sportske ozljede ili oštećenja šake i ručnog zgloba u periodu od 1. 3. 2010. do 31. 3. 2020. u Klinici za ortopediju i traumatologiju Lovran (slika 1).

Od 70 pacijenata uključenih u ovo istraživanje, 56 (80 \%) je muškog spola. Prosječna dob pacijenata bila je $23,7 \pm 8,5$ godina, a raspon dobi pacijenata od 10 do 50 godina. Prosječna dob žena iznosi medijan 19 (25\%- $75 \%$ percentil $15-22$ ) , a kod muškaraca medijan 22,5 (25\% - $75 \%$ percentil $18-28,5)$ godina $(P=0,034)$ (tablica 1$)$.

Razlike s obzirom na spol i zahvaćenu stranu nisu nađene $(P=0,776)$. Kod 35 (50\%) pacijenata bila je zahvaćena lijeva strana [16 šaka (3 žena i 13 muškaraca) i 19 ručnih zglobova (5 žena i 14 muškaraca)] $(P=0,695)$, dok je kod preostalih 35 (50\%) pacijenata bila zahvaćena desna strana [18 
šaka (3 žena i 15 muškaraca) i 17 ručnih zglobova (3 žena i 14 muškaraca)] ( $P=1,000)$ (tablica 1).

U tablici 2 navedeni su podaci o operacijski liječenim pacijentima sa sportskim ozljedama ili oštećenjima u području šake. Od 34 pacijenta, kod njih 20 je učinjena osteosinteza metakarpalne (MTC) kosti i to osteosinteza 1. MTC kosti kod 6 pacijenata (kod 2 pacijenta učinjena je artroskopski asistirana osteosinteza baze 1. MTC kosti), osteosinteza 2. MTC kosti kod 3 pacijenta, osteosinteza 3. MTC kosti također kod 3 pacijenta, osteosinteza 4. MTC kosti kod 3 pacijenta i 1 pacijentice, osteosinteza 5. MTC kosti kod 3 pacijenta te osteosinteza 4. i 5. MTC kosti u istom aktu kod 1 pacijenta. Kod 8 pacijenata učinjena je osteosinteza prijeloma falangi prstiju [proksimalne falange 1., 3. i 4. prsta, srednje falange 5. prsta te distalne falange 2., 3., 4., i 5. prsta (tip III čekićastog prsta kod kojeg je došlo do avulzije koštanog hvatišta ekstenzorne tetive prsta s otrgnućem većeg komada kosti - slika 2). lako su prijelomi MTC kostiju brojčano zastupljeniji u odnosu na prijelome falangi, nije pronađena statistički značajna razlika između prijeloma MTC kostiju i prijeloma falangi prstiju $(P=0,117)$. Kod 3 pacijenta ( 2 pacijenta i 1 pacijentice) zbog ozljede ulnarnog kolateralnog ligamenta metakarpofalangealnog (MCP) zgloba palca učinjena je njegova rekon-

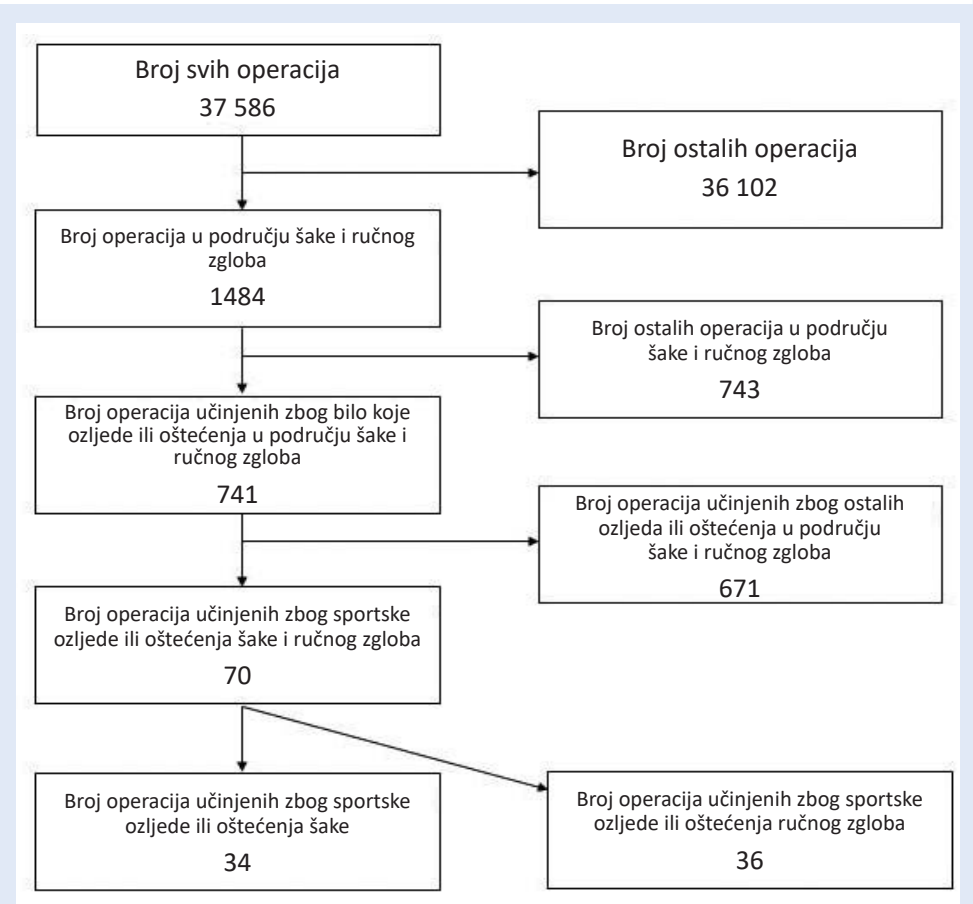

Slika 1. Hodogram postupka pretraživanja Kliničko-bolničkog informacijskog sustava

strukcija. Artrodeza distalnog interfalangealnog (DIP) zgloba 3. prsta učinjena je kod pacijentice pod rednim brojem 18. zbog prethodno neuspjelog liječenja tipa III čekićastog prsta. Kod pacijenta pod rednim brojem 20. (profesionalni kickboksač) učinjena je artrodeza 2. karpometakarpalnog

Tablica 1. Osobine ispitanika uključenih u istraživanje

\begin{tabular}{|c|c|c|c|c|c|c|}
\hline & \multirow{2}{*}{$\begin{array}{c}\text { Broj (\%) } \\
\text { pacijenata }\end{array}$} & \multirow{2}{*}{$\begin{array}{c}\text { Dob (godine) } \\
\text { Medijan (25\% - } 75 \% \text { percentil) }\end{array}$} & \multirow{2}{*}{$\begin{array}{l}\text { Raspon dobi } \\
\text { (godine) }\end{array}$} & \multicolumn{2}{|c|}{ Strana } & \multirow{2}{*}{$P^{*}$} \\
\hline & & & & Lijeva & Desna & \\
\hline šaka & 34 & $\begin{array}{c}22 \\
(18-27)\end{array}$ & $10-44$ & 16 & 18 & \\
\hline muškarci & 28 (82 \%) & $\begin{array}{c}22 \\
(18-30,5)\end{array}$ & $10-44$ & 13 & 15 & \multirow{2}{*}{1,000} \\
\hline žene & $6(18 \%)$ & $\begin{array}{c}18 \\
(15-24,5)\end{array}$ & $12-22$ & 3 & 3 & \\
\hline ručni zglob & 36 & $\begin{array}{c}22 \\
(18-27)\end{array}$ & $11-50$ & 19 & 17 & \\
\hline muškarci & 28 (78 \%) & $\begin{array}{c}25 \\
(18,5-28,5)\end{array}$ & $11-50$ & 14 & 14 & \multirow{2}{*}{0,695} \\
\hline žene & $8(22 \%)$ & $\begin{array}{c}20,5 \\
(14-22)\end{array}$ & $15-30$ & 5 & 3 & \\
\hline Ukupno & 70 & $23,7 \pm 8,5$ & $10-50$ & 35 & 35 & \\
\hline muškarci & 56 (80 \%) & $\begin{array}{c}22,5 \\
(18-28,5)\end{array}$ & $10-50$ & 27 & 29 & \multirow{2}{*}{0,776} \\
\hline žene & $14(20 \%)$ & $\begin{array}{c}19 \\
(15-22)\end{array}$ & $12-30$ & 8 & 6 & \\
\hline
\end{tabular}



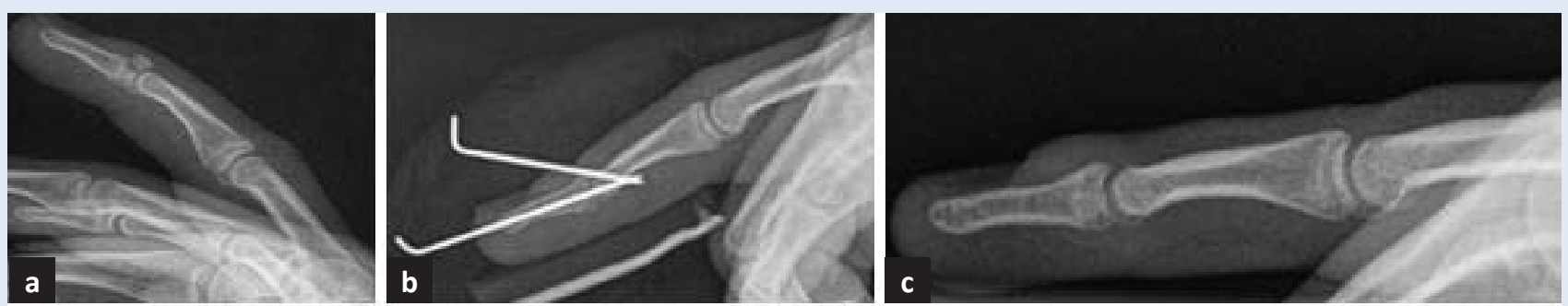

Slika 2. Liječenje koštanog čekićastog prsta: a - prijeoperacijska RTG slika; b - rana poslijeoperacijska RTG slika; c - poslijeoperacijska RTG slika nakon odstranjenja K-žica

Tablica 2. Operacijski liječene sportske ozljede ili oštećenja u području šake u periodu od 1. 3. 2010. do 31. 3. 2020.

\begin{tabular}{|c|c|c|c|c|c|c|c|}
\hline $\begin{array}{c}\text { Redni } \\
\text { broj }\end{array}$ & Dob & Spol & Ozljeda ili oštećenje & Operacijski zahvat & $\begin{array}{l}\text { Sportska } \\
\text { aktivnost koja je } \\
\text { dovela do } \\
\text { ozljede ili } \\
\text { oštećenja }\end{array}$ & $\begin{array}{c}\text { Povratak } \\
\text { sportskim } \\
\text { aktivnostima }\end{array}$ & $\begin{array}{c}\text { Povratak na } \\
\text { istu razinu } \\
\text { sportskih } \\
\text { aktivnosti }\end{array}$ \\
\hline 1. & 28 & $M$ & Prijelom 5. MTC kosti & OS & BS (boks) & / & / \\
\hline 2. & 20 & M & Prijelom 1. MTC kosti (Bennett) & OS & Nogomet & l & l \\
\hline 3. & 26 & M & Prijelom srednje falange 5. prsta & OS & Rukomet & l & I \\
\hline 4. & 38 & M & Prijelom 5. MTC kosti & OS & Nogomet & l & l \\
\hline 5. & 19 & ž & Prijelom distalne falange 2. prsta & OS & Nogomet & l & l \\
\hline 6. & 34 & M & Prijelom 1. MTC kosti (Bennett) & OS & $\mathrm{BS}(\mathrm{MMA})$ & DA & DA \\
\hline 7. & 28 & M & Ruptura UCL palca & Rekonstrukcija UCL palca & Nogomet & / & l \\
\hline 8. & 30 & M & Prijelom 1. MTC kosti (Bennett) & OS & BS (kick boxing) & DA & DA \\
\hline 9. & 31 & M & Prijelom 2. MTC kosti & OS & BS (kick boxing) & DA & DA \\
\hline 10. & 16 & M & Prijelom distalne falange 5. prsta & OS & Rukomet & / & / \\
\hline 11. & 14 & ž & Prijelom proksimalne falange 3 . prsta & OS & Odbojka & l & l \\
\hline 12. & 24 & $M$ & Prijelom proksimalne falange 4 . prsta & OS & Nogomet & / & l \\
\hline 13. & 28 & M & Prijelom 1. MTC kosti (Bennett) & OS & BS (kick boxing) & l & l \\
\hline 14. & 30 & $M$ & Prijelom 3. MTC kosti & OS & Nogomet & l & l \\
\hline 15. & 15 & $M$ & Prijelom 4. MTC kosti & OS & Rukomet & / & l \\
\hline 16. & 22 & ž & Prijelom distalne falange 3. prsta & OS & Odbojka & l & l \\
\hline 17. & 20 & $M$ & Prijelom 1. MTC kosti (Bennett) & AT TMC zgloba + OS 1. MTC kosti & BS (boks) & / & l \\
\hline 18. & 22 & ž & Posttraumatski OA DIP zgloba 3. prsta & Artrodeza DIP zgloba 3. prsta & Odbojka & / & / \\
\hline 19. & 16 & M & Prijelom 5. MTC kosti & OS & Rukomet & DA & DA \\
\hline 20. & 27 & $M$ & Posttraumatski OA 2. CMC zgloba & Artrodeza 2. CMC zgloba & BS (kick boxing) & DA & DA \\
\hline 21. & 18 & M & Prijelom 3. MTC kosti & OS & Nogomet & l & / \\
\hline 22. & 44 & M & Luksacija 4. i 5. CMC zgloba & Repozicija 4. i 5. CMC zgloba & BS (boks) & l & / \\
\hline 23. & 17 & M & Prijelom 3. MTC kosti & OS & Nogomet & l & l \\
\hline 24. & 12 & Ž & Ruptura UCL palca & Rekonstrukcija UCL palca & Nogomet & l & l \\
\hline 25. & 21 & M & Prijelom 4. MTC kosti & OS & Nogomet & I & l \\
\hline 26. & 10 & M & Ruptura UCL palca & Rekonstrukcija UCL palca & Nogomet & l & l \\
\hline 27. & 15 & M & Prijelom distalne falange 4 . prsta & OS & Rukomet & I & l \\
\hline 28. & 29 & M & Prijelom 2. MTC kosti & OS & BS (MMA) & DA & DA \\
\hline 29. & 19 & M & Prijelom 4. MTC kosti & OS & Nogomet & / & l \\
\hline 30. & 28 & M & Prijelom 2. MTC kosti & OS & Rukomet & l & l \\
\hline 31. & 22 & Ž & Prijelom 4. MTC kosti & OS & Odbojka & DA & DA \\
\hline 32. & 21 & M & Prijelom proksimalne falange 1 . prsta & OS & Rukomet & l & l \\
\hline 33. & 28 & M & Prijelom 4. i 5. MTC kosti & OS & Nogomet & / & / \\
\hline 34. & 20 & $M$ & Prijelom 1. MTC kosti (Bennett) & AT TMC zgloba + OS 1. MTC kosti & Košarka & I & I \\
\hline
\end{tabular}

AT - artroskopija, BS - borilački sportovi, CMC - karpometakarpalni, DIP - distalni interfalangealni, M - muški spol, MMA (od engl. Mixed Martial Arts) - mješovite borilačke vještine, MTC - metakarpalna, OA - osteoartritis, OS - osteosinteza, TMC - trapeziometakarpalni, UCL - ulnarni kolateralni ligament, Ž - ženski spol.

I- nema dostupnih podataka 
Tablica 3. Operacijski liječene sportske ozljede ili oštećenja u području ručnog zgloba u periodu od 1. 3. 2010. do 31. 3. 2020.

\begin{tabular}{|c|c|c|c|c|c|c|c|}
\hline $\begin{array}{c}\text { Redni } \\
\text { broj }\end{array}$ & Dob & Spol & Ozljeda ili oštećenje & Operacijski zahvat & $\begin{array}{c}\text { Sportska } \\
\text { aktivnost koja } \\
\text { je dovela do } \\
\text { ozljede ili } \\
\text { oštećenja }\end{array}$ & $\begin{array}{c}\text { Povratak } \\
\text { sportskim } \\
\text { aktivnostima }\end{array}$ & $\begin{array}{c}\text { Povratak na } \\
\text { istu razinu } \\
\text { sportskih } \\
\text { aktivnosti }\end{array}$ \\
\hline 1. & 50 & M & PDR & OS & Skijanje & / & / \\
\hline 2. & 11 & M & PDR & OS & Skijanje & / & l \\
\hline 3. & 40 & M & PDR & OS & Skijanje & l & l \\
\hline 4. & 17 & ž & Pseudartroza skafoida & Matti-Russe & Odbojka & l & / \\
\hline 5. & 15 & M & Ozljeda TFCC (1A) & AT RZ + debridement TFCC & BS (boks) & / & / \\
\hline 6. & 20 & M & PDR & OS & Nogomet & / & / \\
\hline 7. & 22 & M & Ozljeda TFCC (1B) & AT RZ + šivanje TFCC & $\mathrm{BS}(/)$ & I & l \\
\hline 8. & 25 & M & Pseudartroza skafoida & AT RZ + spongioplastika skafoida & BS (džudo) & I & l \\
\hline 9. & 25 & $\check{z}$ & Ozljeda TFCC (1D) & AT RZ + debridement TFCC & Gimnastika & l & l \\
\hline 10. & 23 & M & Ruptura S-L ligamenta & AT RZ & Rukomet & l & l \\
\hline 11. & 22 & M & Pseudartroza skafoida & AT RZ + spongioplastika skafoida & Nogomet & l & / \\
\hline 12. & 30 & $\check{z}$ & Ozljeda TFCC (1B) & AT RZ + šivanje TFCC & Košarka & l & l \\
\hline 13. & 18 & M & TSPLFD & $\begin{array}{c}\text { OS skafoida, rekonstrukcija L-T } \\
\text { ligamenta }\end{array}$ & Nogomet & DA & DA \\
\hline 14. & 15 & ž & Ozljeda TFCC (1B) & AT RZ + šivanje TFCC & Tenis & DA & DA \\
\hline 15. & 21 & M & $\begin{array}{l}\text { Odgođeno sraštavanje skafoida + } \\
\text { ruptura S-L ligamenta }\end{array}$ & AT RZ & Nogomet & DA & DA \\
\hline 16. & 22 & M & Pseudartroza skafoida & AT RZ + spongioplastika skafoida & Rukomet & NE & $\mathrm{NE}$ \\
\hline 17. & 15 & ž & Ozljeda TFCC $(1 \mathrm{~A}+1 \mathrm{~B})$ & $\begin{array}{c}\text { AT } R Z+\text { debridement i šivanje } \\
\text { TFCC }\end{array}$ & Košarka & / & / \\
\hline 18. & 15 & ž & Ozljeda TFCC (1B) & AT RZ + šivanje TFCC & Rukomet & I & l \\
\hline 19. & 18 & M & Prijelom distalnog radiusa i ulne & OS & Nogomet & / & l \\
\hline 20. & 24 & $\check{z}$ & Ozljeda TFCC (1B) & AT ručnog zgloba + šivanje TFCC & Tenis & DA & DA \\
\hline 21. & 11 & M & Ruptura S-L ligamenta & $\begin{array}{l}\text { AT RZ + otvorena rekonstrukcija } \\
\text { S-L ligamenta }\end{array}$ & Nogomet & / & / \\
\hline 22. & 25 & M & TSPLFD & $\begin{array}{c}\text { OS skafoida + rekonstrukcija L-T } \\
\text { ligamenta }\end{array}$ & Nogomet & / & / \\
\hline 23. & 28 & M & Ruptura S-L ligamenta & $\begin{array}{c}\text { AT RZ + otvorena rekonstrukcija } \\
\text { S-L ligamenta }\end{array}$ & Rukomet & / & / \\
\hline 24. & 34 & M & Ozljeda TFCC (1A + 1B) & AT RZ + fovealna reinzercija TFCC & BS (boks) & / & l \\
\hline 25. & 19 & ž & $\begin{array}{l}\text { Ozljeda TFCC (1B) + ruptura S-L } \\
\text { ligamenta }\end{array}$ & AT RZ + šivanje TFCC + ADKLP & Klizanje & l & / \\
\hline 26. & 19 & M & Pseudartroza skafoida & AT RZ + spongioplastika skafoida & BS (boks) & I & l \\
\hline 27. & 24 & M & $\begin{array}{l}\text { Ozljeda TFCC }(1 \mathrm{~A})+\text { ruptura S-L } \\
\text { ligamenta }\end{array}$ & $\begin{array}{l}\text { AT RZ + debridement TFCC + } \\
\text { ADKLP }\end{array}$ & Vaterpolo & / & / \\
\hline 28. & 33 & M & Ruptura S-L ligamenta & $\begin{array}{l}\text { AT RZ + otvorena rekonstrukcija } \\
\text { S-L ligamenta }\end{array}$ & BS (boks) & / & / \\
\hline 29. & 15 & M & Pseudartroza skafoida & AT RZ + spongioplastika skafoida & Nogomet & I & l \\
\hline 30. & 18 & M & Ozljeda TFCC (1B) & AT RZ + šivanje TFCC & Tenis & I & I \\
\hline 31. & 46 & M & Prijelom skafoidne kosti & AT RZ + OS skafoida & Brdski biciklizam & DA & DA \\
\hline 32. & 26 & M & Ruptura S-L ligamenta & $\begin{array}{c}\text { Otvorena rekonstrukcija S-L } \\
\text { ligamenta }\end{array}$ & BS (boks) & / & / \\
\hline 33. & 39 & M & TSPLFD & $\begin{array}{c}\text { OS skafoida + rekonstrukcija L-T } \\
\text { ligamenta }\end{array}$ & Nogomet & / & / \\
\hline 34. & 21 & M & Pseudartroza skafoida & AT RZ + spongioplastika skafoida & Nogomet & I & l \\
\hline 35. & 18 & M & Pseudartroza skafoida & AT RZ + spongioplastika skafoida & Rukomet & l & l \\
\hline 36. & 40 & M & Ozljeda TFCC (1B) & AT RZ + šivanje TFCC & Tenis & l & l \\
\hline
\end{tabular}

ADKLP - artroskopska dorzalna kapsulo-ligamentoplastika, AT - artroskopija, BS - borilački sportovi, L-T - luno-trikvetralni, M - muški spol, OS - osteosinteza, PDR - prijelom distalnog radiusa, RZ - ručni zglob, S-L - skafo-lunatni, TFCC - triangularni fibrokartilaginozni kompleks, TSPLFD - trans-skafoidna perilunatna frakturna dislokacija, Ž - ženski spol.

/ - nema dostupnih podataka 
(CMC) zgloba poradi razvoja posttraumatskog osteoartritisa (OA). Repozicija i stabilizacija 4. i 5. karpometakarpalnog (CMC) zgloba učinjena je kod rekreativnog boksača zbog luksacije 4. i 5. CMC zgloba. Od 34 operacije 30 operacija učinjeno je unutar 6 tjedana od nastanka ozljede, artrodeza DIP zgloba 3. prsta učinjena je kod pacijentice pod rednim brojem 18. nakon 2 mjeseca od ozljede, dok su preostale 3 operacije učinjene zbog oštećenja kroničnog karaktera (za koja nije moguće utvrditi točan datum nastanka) kao što je kronična ruptura ulnarnog kolateralnog ligamenta (UCL) MCP zgloba palca (rekonstrukcija UCL MCP zgloba palca kod pacijenta pod rednim brojem 7. i kod pacijentice po rednim brojem 24.) ili posttraumatski OA 2. CMC zgloba (artodeza 2. CMC zgloba kod pacijenata pod rednim brojem 20.). Sportska aktivnost koja je dovela do ozljede ili oštećenja u području šake bila je kod 11 pacijenata i 2 pacijentice nogomet, kod 9 pacijenata borilački sportovi (kick boxing, MMA, boks), kod 7 pacijenata rukomet, kod 4 pacijentice odbojka i kod 1 pacijenta košarka. Od 34 pacijenta, kod njih 7 (21 \%) (5 borilački sportovi, 1 rukomet i 1 odbojka - svi su se bavili sportskom aktivnošću profesionalno) zabilježen je povratak na istu razinu sportskih aktivnosti kao i prije ozljede, dok kod preostalih 27 (79\%) pacijenata (1 pacijent se bavio sportskom aktivnošću profesionalno, ostalih 26 rekreativno) nema dostupnih podataka o tome jesu li se vratili sportskim aktivnostima ili ne i, ako jesu, radi li se o istoj razini sportske aktivnosti kao i prije ozljede.

U tablici 3 navedeni su podaci o operacijski liječenim pacijentima sa sportskim ozljedama ili oštećenjima u području ručnog zgloba. Od 36 pacijenata, kod njih 26 je učinjena artroskopija ručnog zgloba i to kao samostalna procedura kod 3 pacijenta ili u kombinaciji s dodatnim procedurama koje su učinjene tijekom artroskopije ručnog zgloba [debridement i/ili šivanje triangularnog fibrokartilaginozbog kompleksa (TFCC) (slika 3), fovealna reinzercija TFCC, artroskopska spongioplastika skafoidne kosti, artroskopski asistirana osteosinteza skafoidne kosti i artroskopska dorzalna kapsuloligamentoplastika] i nakon artroskopije ručnog zgloba (otvorena rekonstrukcija skafo-lunatnog ligamenta) kod 16 pacijenata i 7 pacijentica. U preostalih 10 pacijenata, kod 5 pa- cijenata je učinjena osteosinteza prijeloma distalnog radiusa, kod 3 pacijenta učinjena je otvorena osteosinteza skafoidne kosti uz rekonstrukciju luno-trikvetralnog ligamenta zbog transskafoidne perilunatne frakturne dislokacije, kod 1 pacijenta otvorena rekonstrukcija skafo-lunatnog ligamenta zbog rupture istoga i kod 1 pacijentice kortikospongioplastika pseudartroze skafoidne kosti po Matti-Russeu. Od 36 operacija, 9 operacija je učinjeno unutar $6 \mathrm{tj}$. od nastanka ozljede (kod pacijenata pod rednim brojevima 1., 2., 3., 6., 13., 19., 22., 31. i 33.), dok je preostalih 27 operacija učinjeno zbog oštećenja kroničnog karaktera (za koja nije moguće utvrditi točan datum nastanka). Za razliku od operacijski liječenih sportskih ozljeda u području šake (od 34 operacije, 31 operacija učinjena je zbog ozljede, 3 operacije zbog oštećenja), učestalije je operacijsko liječenje sportskih oštećenja negoli ozljeda u području ručnog zgloba (od 36 operacija, 9 operacija je učinjeno zbog ozljede, a 27 operacija zbog oštećenja) ( $P$ < 0,001). Sportska aktivnost koja je dovela do ozljede ili oštećenja u području ručnog zgloba bila je nogomet kod 10 pacijenata, borilačke vještine (džudo, boks) kod 7 pacijenata, rukomet kod 4 pacijenta i 1 pacijentice, tenis kod 2 pacijenta i 2 pacijentice, skijanje kod 3 pacijenta, košarka kod 2 pacijentice, odbojka kod 1 pacijentice, gimnastika kod 1 pacijentice, klizanje kod 1 pacijentice, vaterpolo kod 1 pacijenta i brdski biciklizam kod 1 pacijenta. Od 36 pacijenata, kod njih 5 (14\%) (2 nogomet i 2 tenis - profesionalni sportaši i 1 brdski biciklizam - rekreativni sportaš) zabilježen je

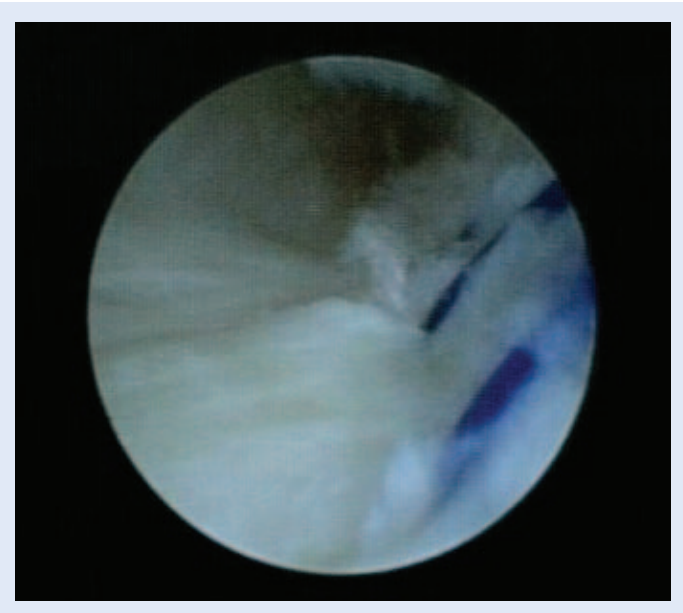

Slika 3. Artroskopsko šivanje ozljede triangularnog fibrokartilaginoznog kompleksa (TFCC) 
povratak na istu razinu sportskih aktivnosti kao i prije ozljede, kod 1 pacijenta (redni broj 16.) došlo je do prekida bavljenja sportom kojim se (rekreativno) bavio prije nastale ozljede ručnog zgloba, dok kod preostalih 30 (83 \%) pacijenata (1 pacijent se bavio sportskom aktivnošću profesionalno, ostalih 29 rekreativno) nema dostupnih podataka o tome jesu li se vratili sportskim aktivnostima ili ne i, ako jesu, radi li se o istoj razini sportske aktivnosti kao i prije ozljede.

\section{RASPRAVA}

Ovo je prvo istraživanje u našoj populaciji kojim su dobiveni podaci o vrstama sportskih ozljeda i oštećenja ručnog zgloba i šake koje su liječene operacijski u posljednjih 10 godina. U našem istraživanju učestalost operacijski liječenih sportskih ozljeda (ili oštećenja) ručnog zgloba i šake u posljednjih 10 godina u odnosu na sve operacije u području ručnog zgloba i šake zbog bilo koje ozljede (ili oštećenja) iznosi 9,4\%. Pretraživanjem literature nismo uspjeli pronaći sličan podatak o učestalosti operacijskog liječenja sportskih ozljeda ručnog zgloba i šake u odnosu na operacijsko liječenje bilo koje ozljede ili oštećenja u području ručnog zgloba i šake. Prema istraživanju Bartelsa i sur. učestalost operacijski liječenih ozljeda ručnog zgloba i šake, a koje je obuhvatilo 725 ozljeda ručnog zgloba i šake, iznosila je 7,4 $\%{ }^{13}$.

Što se tiče distribucije operacijski liječenih sportskih ozljeda ili oštećenja ručnog zgloba i šake među spolovima u našem istraživanju, vidljivo je da je $80 \%$ ispitanika muškog spola koji su se pretežito bavili borilačkim ili kontaktnim sportovima (npr. nogomet). To se može objasniti činjenicom da se više pripadnika muškog spola bavi borilačkim sportovima ili nogometom prilikom kojih se vrlo često zadobiju ozljede ili oštećenja šake i ručnog zgloba koje je potrebno operacijski liječiti. Nismo uspjeli pronaći istovjetni podatak iz drugih istraživanja s kojim bismo mogli usporediti naš rezultat. Kada se uzme u obzir distribucija operacijski liječenih sportskih ozljeda ili oštećenja ručnog zgloba i šake po dobi među spolovima, žene su mlađe od muškaraca. Ozljede ručnog zgloba i šake najčešće su u dobnoj skupini od 20 do 29 godina $^{14}$. S obzirom na to da je prosjek dobi ispitanika uključenih u ovo istraživanje 23,7 godine, možemo za- ključiti da se taj podatak podudara s podacima iz literature.

Iz rezultata ovog istraživanja vidljiva je jednakomjerna zastupljenost lijeve i desne strane kod operacijski liječenih ozljeda i oštećenja ručnog zgloba i šake, kao i gotovo jednakomjerna zastupljenost ozljeda i oštećenja šake i ozljeda i oštećenja ručnog zgloba. Naši rezultati, što se tiče zastupljenosti strane koja je ozlijeđena, nisu u skladu s rezultatima istraživanja Bartona koji navodi da su sportske ozljede šake i ručnog zgloba 3 puta češće desnostrano ${ }^{15}$.

S obzirom na provizornu podjelu sportskih ozljeda i oštećenja šake i ručnog zgloba korištenu u našem istraživanju na sportske ozljede ili oštećenja šake i sportske ozljede ili oštećenja ručnog zgloba (opisano u Ispitanicima i metodama), nismo uspjeli pronaći podatke u literaturi s kojima bismo usporedili naše rezultate.

Analizirajući u našem istraživanju operacijski liječene sportske ozljede ili oštećenja u području šake, najzastupljeniji su operacijski zahvati prijeloma MTC kostiju i falangi prstiju (u 82 \% pacijenata). Rezultati našeg istraživanja podudaraju se s podacima iz literature, što se tiče zastupljenosti prijeloma kao najčešćih sportskih ozljeda šake, međutim, ne podudaraju se s podacima iz literature kada se tiče učestalosti pojedinih prijeloma u području šake ${ }^{16-17}$. Naime, iako su u našem istraživanju brojčano zastupljeniji prijelomi MTC kostiju u odnosu na prijelome falangi, nije pronađena statistički značajna razlika između prijeloma MTC kostiju i prijeloma falangi prstiju $(P=0,117)$. $U$ drugim istraživanjima češći su prijelomi falangi u odnosu na prijelome MTC kostiju ${ }^{16-17}$. Prijelomi MTC kostiju i falangi najviše su zastupljeni u borilačkim i kontaktnim sportovima (npr. nogomet, rukomet itd.), što se podudara s rezultatima našeg istraživanja. Jedna od čestih sportskih ozljeda u području šake je i ozljeda ulnarnog kolateralnog ligamenta MCP zgloba palca, što se podudara $\mathrm{S}$ rezultatima našeg istraživanja, s obzirom na činjenicu da je ona 3. po zastupljenosti svih operacijski liječenih sportskih ozljeda šake u našem istraživa$\mathrm{nju}^{18}$.

Za razliku od operacijski liječenih sportskih ozljeda u području šake, prema rezultatima našeg istraživanja pronađena je statistički značajna razli- 
ka $(P<0,001)$ između operacijski liječenih sportskih oštećenja u području ručnog zgloba u odnosu na operacijski liječene sportske ozljede u području ručnog zgloba. Kao i kod operacijski liječenih sportskih ozljeda u području šake, operacijsko liječenje sportskih oštećenja u području ručnog zgloba najviše je zastupljeno u sportaša koji se bave borilačkim i kontaktnim sportovima (npr. nogomet, rukomet, košarka itd.). Operacijski liječene sportske ozljeda ručnog zgloba, kao što su prijelomi distalnog radijusa, prijelomi skafoida i transskafoidna perilunatna frakturna dislokacija, najviše su zastupljeni kod nogometaša i skijaša.

Jedan od nedostataka ovog istraživanja jest taj da ono nije uključilo sve sportske ozljede ručnog zgloba i šake koji su liječeni neoperacijski u posljednjih 10 godina u Klinici za ortopediju i traumatologiju Lovran. Također, analizom dostupnih podataka iz KIBIS-a i arhive Klinike za ortopediju i traumatologiju Lovran za većinu sportskih ozljeda i oštećenja šake i ručnog zgloba nije bilo moguće utvrditi jesu li se sve osobe uključene u ovo istraživanje vratile bavljenju istim sportskim aktivnostima kojim su se bavile prije nastale sportske ozljede ili oštećenja i, ako jesu, na koju su se razinu sportske aktivnosti vratile.

Epidemiološki podaci prikupljeni ovim istraživanjem predstavljaju temelj za daljnja istraživanja o danoj tematici.

\section{ZAKLJUČCI}

Gotovo $10 \%$ operacija u području ručnog zgloba i šake su operacije sportskih ozljeda i oštećenja. Operacijsko liječenje sportskih ozljeda šake češće je od operacijskog liječenja sportskih oštećenja šake, a najčešći uzrok operacijskog liječenja sportskih ozljeda šake su prijelomi. Operacijsko liječenje sportskih oštećenja ručnog zgloba češće je od operacijskog liječenja sportskih ozljeda ručnog zgloba, a najčešći uzrok operacijskog liječenja sportskih oštećenja ručnog zgloba su ozljede mekih tkiva.

Izjava o sukobu interesa: Autori izjavljuju da ne postoji sukob interesa.

\section{LITERATURA}

1. Timpka T, Finch CF, Goulet C, Noakes T, Yammine K. Safe Sports International Board. Meeting the global demand of sports safety: the intersection of science and policy in sports safety. Sports Med 2008;38:795-805.

2. Medibank.com.au [Internet]. Medibank Private Limited [cited 2020 April 16]. Available from: https://www. medibank.com.au/content/dam/retail/about-assets/ pdfs/investor-centre/annual-reports/MPL_Annual_ Report_2006.pdf.

3. Kisser R, Bauer R. Sport injuries in the European Union. Inj Prev 2010;16:A1-A289.

4. Joseph C, Finch CF. Sports Injuries. In: Quah SR (ed). International Encyclopedia of Public Health (Second Edition). Cambridge, Massachusetts: Academic Press, Elsevier, 2017;79-86.

5. Finch $\mathrm{CF}$, Kemp JL, Clapperton AJ. The incidence and burden of hospital-treated sports-related injury in people aged 15+ years in Victoria, Australia, 2004-2010: a future epidemic of osteoarthritis?. Osteoarthritis Cartilage 2015;23:1138-43.

6. Noyes FR, Lindenfeld TN, Marshall MT. What Determines an Athletic Injury (Definition)? Who Determines an Injury (Occurrence)? Am J Sports Med 1988;16(1_suppl).

7. Timpka T, Jacobsson J, Ekberg J, Nordenfeldt L. What is a sports injury? Br J Sports Med 2011;45:376.

8. Timpka T, Jacobsson J, Bickenbach J, Finch CF, Ekberg J, Nordenfelt L. What is a sports injury? Sports Med 2014; 44:423-8.

9. Pećina M. Športska medicina. 2. izdanje. Zagreb: Medicinska naklada, 2004.

10. Rettig AC. Epidemiology of hand and wrist injuries in sports. Clin Sports Med 1998;17:401-6.

11. Rettig AC. Athletic injuries of the wrist and hand. Part 1. Traumatic injuries of the wrist. Am J Sports Med 2003; 31:1038-48.

12. Amadio PC. Epidemiology of hand and wrist injuries in sports. Hand Clin 1990;6:379-81.

13. Bartels DW, Hevesi M, Wyles C, Macalena J, Kakar S, Krych AJ. Epidemiology of Hand and Wrist Injuries in NCAA Men's Football: 2009-2010 to 2013-2014. Orthop J Sports Med 2019;7:2325967119835375.

14. Shrestha S., Tamrakar S., Banskota AK. Outline of Hand and Wrist Injuries Presenting to an Emergency of a Tertiary Care Centre in Nepal. J Nepal Health Res Counc 2019;17:340-4.

15. Barton N. Sports injuries of the hand and wrist. $\mathrm{Br} J$ Sports Med 1997;31:191-196.

16. Curtin J, Kay NRM. Hand injuries due to soccer. Hand 1976;8:93-5.

17. Aitken S, Court-Brown CM. The epidemiology of sportsrelated fractures of the hand. Injury 2008;39:1377-83.

18. Avery DM 3rd, Rodner CM, Edgar CM. Sports-related wrist and hand injuries: a review. J Orthop Surg Res 2016;11:99. 